https://doi.org/10.31470/2706-7904-2020-15-35-38

\title{
ПСИХОЛІНГВІСТИЧНИЙ РОЗВИТОК МОВЛЕННЯ ДІТЕЙ ДОШКІЛЬНОГО ВІКУ ЗАСОБАМИ ОНТОМУЗИКОТЕРАПІЇ
}

\author{
Psycholinguistic Speech Development of Preschool Age Children \\ by Ontomusictherapy
}

\author{
Iryna Volzhentseva \\ DSc. in Psychology, Professor \\ Pereiaslav-Khmelnytskyi Hryhorii Skovoroda State Pedagogical University (Ukraine) \\ iv.volzhentseva@gmail.com \\ https://orcid.org/ 0000-0003-0458-531X
}

\begin{abstract}
Absrtact
The article reveals the innovative aspects of preschool age children's speech development by means of ontomusic therapy due to the interaction and relationship of the prosody components and means of musical expression according to the deep psychology of the mechanisms of psyche functioning of J. Lacan and the theory of the active form of music therapy by A. Meneghetti.
\end{abstract}

Key words: speech, preschoolers, development, prosodic component of speech, ontomusic therapy, interaction, interplay, relationship.

\section{Ветуп \\ Introduction}

Просодичний компонент мовлення: дикція (чітка, змазана, незрозуміла); темп (нормальний, прискорений, уповільнений); ритм (нормальний, аритмія); інтонація (наявність чи відсутність основних видів інтонації (розповідної, питальної, окличної); паузи (наявність чи відсутність розстановки пауз у мовленнєвому поточі); наголос (наявність чи відсутність інтенсивності звучання при промовлянні окремих складів слів) взаємопов'язаний із засобами музичної виразності, такими, як: ритм (чергування довгих і коротких звуків), темп (ивидкість виконання музичного твору), інтонація (найменша частина мелодї, щуо має виразне значення), тембр (забарвлення, характер звуку), динаміка (сила звучання звуку), гармонія («співзвуччя», спосіб виразності в музиці), пауза (знак мовчання), щцо зумовлює ӥх взаємодію, взаємовідношення і психоемоційні взаємовпливи. 
Mema cmammi - описати згідно концепції Ж. Лакана (Лакан, 1995) про глибинну психологію механізмів функціонування психіки; теорії активної форми музикотерапії А. Менегетті (Менегетти, 1999) про розвиток просодичного компонента мовлення засобами онтомузикотерапії; психофізіологічної теорії І.В. Волженцевої $(2016,2017)$ про розвиток емоційно-виразної сторони мовлення, результати експериментального дослідження впливу онтомузикотерапії на розвиток просодичного компонента мовлення.

\section{Методи дослідження}

\section{Methods of the Research}

Для розв’язання дослідницької проблеми було використано такі методи дослідження: теоретичні - теоретико-методологічний аналіз наукових джерел $\mathrm{i}$ наявних у науковому обігу психологічних підходів, їх систематизація, класифікація, узагальнення, моделювання та висновування для вивчення феномена «просодичний компонент мовлення» й стану дослідженості проблематики розвитку просодичного компонента мовлення дітей дошкільного віку; емпіричні - спостереження, бесіда, анкетування, тестування, які використано для більш глибокого, цілісного вивчення особливостей просодичного компонента мовлення в дітей дошкільного віку; методи математичної статистики - t-критерій Стьюдента - для оцінки вірогідності отриманих результатів.

\section{Результати \\ Results}

Аналізуючи базу експериментальних даних за кількісними показниками та якісними характеристиками, необхідно відмітити, що, будучи багатогранним засобом, онтомузикотерапія за допомогою звуку, вокалу, ритму, руху, дій у співі безпосередньо впливає як на просодичний компонент мовлення через правильну організацію мовленнєвого дихання, темпо-ритмічну організацію та інші параметри, так і опосередковано, трансформуючи такі психологічні особливості як емоційність, творчі прояви, креативність, що позитивно позначається на якісному розвитку просодики усного мовлення дітей дошкільного віку.

У результаті емпіричного дослідження виявлено психологічні особливості зміни складових просодичного компонента мовлення. Розвиткові мовленнєвих умінь i навичок притаманна стійка прискорена динамічність становлення мовленнєвих здібностей, стрімкий перехід їх на вищі рівні досконалості: з низького рівня до 
високого (темп, інтонація, логічний наголос, тембр) та середнього (ритм, модуляція голосу за висотою й силою, мовленнєве дихання).

Так, прискорений або уповільнений темп став нормативним; монотонність змінилася інтонаційно, збагатившись відповідно додатковими обертонами розповідної, окличної та питальної інтонації при вимовлянні простих і простих поширених речень; недостатньо розвинуте вміння виділяти головну частину, тобто правильно продукувати логічний наголос, змінилося на більш гучніше й протяжніше підкреслення голосом головних за сенсом слів у фразі; недостатнє володіння тембровою окраскою голосу - здатність змінювати тембр для передачі емоцій i почуттів (веселий або сумний, лагідний або грубий та ін.) відповідно до ситуацій у спілкуванні; недосконалі операції використання ритмічних структур мовлення змінилися на правильне відтворення ізольованих й акцентованих ударів, а також серії простих ударів; недосконале відтворення звуконаслідувань із пониженням i підвищенням висоти голосу розвинулося до володіння власним голосом, розширенням його діапазону, операціями інтонування поступового руху мелодії знизу вгору та зверху вниз; занадто тиха або гучна вимова стала оптимальною за силою (гучністю); не сформованість, поверховість мовленнєвого дихання (вдих переривчастий, іноді з підняттям плечей, зниження обсягу й сили видиху, зайві паузи) змінилися збільшенням об'єму та сили видиху, раціональним розподілом дихання й діафрагмовим типом дихання замість верхньогрудного мовленнєвого дихання.

Розвиток креативності, емоційності, творчих проявів як психологічних детермінант розвитку одиниць просодики мовлення, зумовили переживання почуття душевного комфорту, мобілізації роботи пізнавальних процесів, швидку адаптацію в системі навчально-виховної діяльності, комунікативну активність, толерантність та якісну мовленнєву репрезентацію дошкільника при виконанні вокальнопсихологічних і мовленнєвих вправ.

Отже, розроблена нами психотехнологія онтомузикотерапії суттєво поліпшила звуко-орфоепічні, мовленнєві параметри просодики (сприйняття та відтворення ритму, інтонації, логічного наголосу, тембру, темпо-ритмичної організації, модуляції голосу за висотою й силою, мовленнєве дихання), а також підвищило рівень креативності, емоційності, творчої уяви, поліпшила комунікативність і самооцінку.

\section{Висновки \\ Conclusions}

Під час проведення формувального експерименту доведено розвиваючий вплив запропонованої онтомузикотерапії на просодичні компоненти мовлення дітей 
Psycholinguistics in a Modern World - 2020. Proceedings of the 15th International Scientific and Practical Conference (Pereiaslav-Khmelnytskyi, 22-23 October, 2020)

дошкільного віку засобами активного співу 3 метою їх розвитку, зокрема підвищилися показники: (а) сприйняття та відтворення ритму; (б) модальні смисли інтонації; (в) смислорозрізнююче навантаження логічного наголосу; (г) звукове вираження тембру, що створює ті чи інші емоційно-експресивні відтінки індивідуального мовлення дитини; г) темпо-ритмічної організації, що проявилося в здатності дітей будувати одиниці мовлення за інтонаційними й ритмічними моделями; (д) модуляції голосу за силою, висотою, а також (е) якісно змінилося мовленнєве дихання. Принциповим позитивним чинником $є$ підвищення рівня креативності, емоційності, творчих проявів в дітей дошкільного віку та суттєве поліпшення в них навиків комунікативності, здатності до взаємодії з однолітками й дорослими, а також підвищення самооцінки.

\section{Література References}

Волженцева, І.В. (2017). Развитие эмочионально-выразительной стороны речи дошкольника средствами онтопсихологической музыкотерапии. Psycholinguistics, 22(1), 26-42. https://doi.org/10.5281/zenodo.1087462

Волженцева, І.В. (2016). Эмочиональность как основа развития просодического компонента речи дошкольника. Тези ХІ Міжнародної науково-практичної конферечії «Психолінгвистика в сучасному світі - 2016» (Переяслав-Хмельницький, 20-21 жовтня 2016 р.), (с. 27-29). Переяслав-Хмельницький: ФОП Домбровська Я.М.

Лакан, Ж. (1995). Функиия и поле речи и языка в психоанализе. Москва: Гнозис.

Менегетти, А. (1999) Введение в теорию онтопсихологической музыкотерапии. Методы эффективной психокоррекции. (Хрестоматия). Минск: Харвест. 